\section{Commentary: To flip or not to flip: Approaching the minimally invasive lobectomy}

\author{
Ramiro Fernandez, MD, and \\ Usman Ahmad, MD, FACS
}

A minimally invasive approach to lobectomy has become the standard of care for early-stage lung cancer due to reduced perioperative morbidity and equivalent oncologic outcomes compared to open lobectomy. ${ }^{1,2}$ Mostly to ensure safe dissection, various approaches (anterior, posterior, fissureless) and steps in controlling hilar structures have been described, each with its own merits. The posterior, bronchus-first approach is a hallmark of open right upper lobectomy, whereas the anterior-to-posterior approach was popularized for video assisted thoracic surgery (VATS) lobectomy. ${ }^{3}$ This change in conduct of the operation played a role in impeding widespread adoption of the VATS approach early on. ${ }^{4}$

The robotic platform holds promise in increasing the adoption of minimally invasive lobectomy, offering improved dexterity, better visualization, and shortened learning curve compared with VATS. ${ }^{5}$ In their excellent video atlas, Sasankan and colleagues ${ }^{6}$ describe their robotic right upper lobectomy technique using a posterior-toanterior approach that is reminiscent of the traditional open lobectomy approach through a posterolateral thoracotomy. ${ }^{6}$

The authors describe their technique as very efficient since the lung is never retracted posteriorly for dissection of the anterior hilum. However, it is extremely important to put this in context of the operation being performed by a very experienced surgeon. A trainee or young surgeon should exercise extreme caution in identifying hilar structures. Safety or effectiveness must never be sacrificed for the sake of

\footnotetext{
From the Department of Cardiothoracic Surgery, Heart and Vascular Institute, Cleveland Clinic, Cleveland, Ohio.

Disclosures: The authors reported no conflicts of interest.

The Journal policy requires editors and reviewers to disclose conflicts of interest and to decline handling or reviewing manuscripts for which they may have a conflict of interest. The editors and reviewers of this article have no conflicts of interest.

Received for publication March 30, 2021; revisions received March 30, 2021; accepted for publication March 31, 2021; available ahead of print April 3, 2021.

Address for reprints: Usman Ahmad, MD, FACS, Department of Cardiothoracic Surgery, Heart and Vascular Institute, Cleveland Clinic, Cleveland, OH 44195 (E-mail: ahmadu@ccf.org).

JTCVS Techniques 2021;7:283-4

2666-2507

Copyright (C) 2021 The Authors. Published by Elsevier Inc. on behalf of The American Association for Thoracic Surgery. This is an open access article under the CC BY-NCND license (http://creativecommons.org/licenses/by-nc-nd/4.0/).

https://doi.org/10.1016/j.xjtc.2021.03.035
}

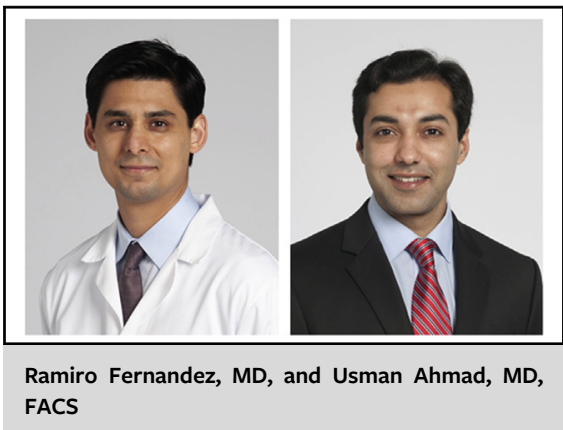

CENTRAL MESSAGE

Expertise in and familiarity with various approaches to minimally invasive lobectomy are necessary for conducting these procedures safely.

efficiency. Retraction of the right upper lobe and lung to dissect both the anterior and posterior hilar structures as necessary should be the standard until the operator is extremely comfortable with 3-dimensional visualization of hilar anatomy in a deflated lung. In some patients, anatomic constraints, such as aberrant vasculature or bulky lymphadenopathy, may necessitate a combination of anterior and posterior approaches to complete the lobectomy. When undertaking the posterior approach, care should be taken to identify and preserve the phrenic nerve, which can sometimes be tethered to the anterior aspect of the superior pulmonary vein. Moreover, as demonstrated in the video, the upper lobe branches of superior pulmonary vein can be difficult to isolate from the posterior approach, and some of these branches may have to be ligated with the parenchyma while completing the minor fissure. A posterior ascending pulmonary artery branch with proximal origin can also be jeopardized if not visualized appropriately. Diligent review of preoperative imaging can identify anatomic variations and prevent intraoperative surprises. Preventing prolonged air leaks after lobectomy remains a key challenge for thoracic surgeons. ${ }^{7}$ Avoiding fissure dissection, especially in patients with incomplete fissures, can be helpful in reducing the risk of prolonged air leak. Appropriate exposure through a combination of posterior and anterior approaches may allow mitigation of some of these risks.

This combination of videos describing a stepwise approach is an invaluable resource for the novice as well as the expert thoracic surgeon in understanding the benefits and challenges of the posterior approach to right upper lobectomy. The 
lessons imparted in this masterful compilation are applicable to open, thoracoscopic, and robotic approaches.

\section{References}

1. Yang CF, Sun Z, Speicher PJ, Saud SM, Gulack BC, Hartwig MG, et al. Use and outcomes of minimally invasive lobectomy for stage I non-small cell lung cancer in the National Cancer Data Base. Ann Thorac Surg. 2016;101:1037-42.

2. Yang HX, Woo KM, Sima CS, Bains MS, Adusumilli PS, Huang J, et al. Longterm survival based on the surgical approach to lobectomy for clinical stage I nonsmall cell lung cancer: comparison of robotic, video-assisted thoracic surgery, and thoracotomy lobectomy. Ann Surg. 2017;265:431-7.
3. McElnay P, Casali G, Batchelor T, West D. Adopting a standardized anterior approach significantly increases video-assisted thoracoscopic surgery lobectomy rates. Eur J Cardiothorac Surg. 2014;46:100-5.

4. Blasberg JD, Seder CW, Leverson G, Shan Y, Maloney JD, Macke RA Video-assisted thoracoscopic lobectomy for lung cancer: current practice patterns and predictors of adoption. Ann Thorac Surg. 2016;102:1854-62.

5. Louie BE, Vallières E. Transitioning from open to robotic lung surgery. Video Assist Thorac Surg. 2020;5:26.

6. Sasankan P, Chang S, Cerfolio R. Robotic right upper lobectomy: twelve steps. J Thorac Cardiovasc Surg Tech. 2021;7:280-2.

7. Ng T, Ryder BA, Machan JT, Cioffi WG. Decreasing the incidence of prolonged air leak after right upper lobectomy with the anterior fissureless technique. J Thorac Cardiovasc Surg. 2010;139:1007-11. 